\section{The Social and Economic Challenges of Nanotechnology}

\author{
Stephen J. Wood, Alison Geldart, Institute of \\ Work Psychology, University of Sheffield; \\ Richard A.L. Jones, Dept of Physics and \\ Astronomy, University of Sheffield
}

\begin{abstract}
A recent study at the University of Sheffield (UK) investigates the social and economic challenges of nanotechnology. In the project, social and natural scientists worked together to provide a careful assessment of the emerging new science of nanotechnology. In addition, the role social science can play in nanotechnology's development is discussed. Nanotechnology is seen as an opportunity to investigate broader themes, such as an evaluation of the drivers behind the technology development process and how society deals with risks under uncertainty.
\end{abstract}

Nanotechnology is being heralded as a new technological revolution, one so profound that it will touch all aspects of human society. For some these influences will be overwhelmingly positive, while others see more sinister implications. In July 2003, the UK's research council dealing with economic and social science, the ESRC, published a report assessing this debate ${ }^{1}$. We summarise the key messages of this report here.

Definitions of nanotechnology are not always clear or indeed agreed upon. The domain of nanotechnology is defined in terms of a length-scale - from 1 nanometer up to 100 nanometers - and by the appearance at these length-scales of different physical properties. These derive from the importance at small length-scales of physical phenomena that are less obvious for larger objects, such as quantum mechanics, strong surface forces and Brownian motion.

Nanotechnology will produce economic and social impacts on three broad timescales. Current applications of nanotechnology are largely the result of incremental advances in already well-established branches of applied science, such as material science and colloid technology. Medium term applications of nanotechnology will apply principles only now being established in the laboratory to overcome foreseeable barriers to continued technological progress. In the long term, entirely new applications may emerge from developments that are currently only anticipated in the laboratory. Whether these include the sort of functional nanodevices able to assemble materials from molecular components remains to be seen.

Current applications for nanotechnology are dominated by tools for scientists, on the one hand, and new materials that are structured on the nanoscale on the other. These new materials currently find applications in cosmetics, health and medicine and in a variety of manufactured goods. The electronics and information technology industries are also a prominent driver for these new technologies.

Debate on the social implications of nanotechnology has largely focused, not on the relatively mundane applications that have arrived so far, but on the longer-term possibilities of radical nanotechnology. This anticipates a degree of control over matter on the nanoscale that permits fabrication from a molecular level of virtually any material or structure. While there is some debate about whether this vision is actually realisable, amongst those who accept it the discussion focuses on rather extreme, utopian or dystopian outcomes.

There is also an emerging debate amongst those more focused on short-term outcomes. This pits those who believe that the rapid growth of nanotechnology will have strongly positive economic benefits, and those who on the grounds of environmentalism and social equity seek to slow or even halt its development. One immediate issue that is growing in prominence is the question of whether existing regulatory regimes are robust enough to deal with any special qualities that nanostructured materials may have, or whether new solutions are required.

These diverging views on nanotechnology and the increasingly public debate, involving civil society, non-governmental organisations and the media, have led to concerns by some that there will be a backlash against nanotechnology akin to that over genetic modification. In response the call is for social science to take a role focused on promoting social awareness and acceptance of nanotechnology.

The agenda for the social sciences needs to be broader than the public-science interface. Three themes stand out as important: 
- The governance of technological change

- Social learning and the evaluation of risk and opportunity under uncertainty

- The role of new technology in ameliorating or accentuating equity and economic divides

Tackling these themes will entail a range of social science issues, many of which are currently highly topical, independently of nanotechnology, e.g. technology transfer, ageing, the commercialisation of science, change management. Nonetheless there may well be issues unique to nanotechnology, arising from its inherent inter-disciplinarity and capacity to change human-machine-nature interface. A programme of research designed to address the diverse social science issues should thus both build on existing research and develop fresh avenues, particularly through developing interdisciplinary work that straddles social sciences, natural sciences and engineering.

\section{Note}

1) The Economic and Social Challenges of Nanotechnology, by S.J. Wood, A. Geldart and R.A.L. Jones. Available from the ESRC (ESRC External Relations Division, Polaris House, North Star Avenue, Swindon SN2 1UJ, UK) or electronically

http://www.esrc.ac.uk/esrccontent/

DownloadDocs/Nanotechnology.pdf

\section{Contact}

Professor Richard A.L. Jones

Dept of Physics and Astronomy

University of Sheffield

Hicks Building, Hounsfield Road

Sheffield, S3 7RH, UK

Tel.: +44 - 114 - 2224530

Fax: +44 - 114 - 2728079

E-Mail: r.a.1.jones@shef.ac.uk

》)

\section{Cyberscience: Forschung im Zeitalter des Internets}

\author{
von Michael Nentwich, Institut für Technik- \\ folgen-Abschätzung (ITA), Wien
}

\begin{abstract}
Informations- und Kommunikationstechnologien (IKT) haben längst den Altag der Wissenschafterlnnen erobert. Elektronische Zeitschriften werden ubiquitär sein, virtuelle Volltext-Bibliotheken überall zur Verfügung stehen, Multimedia und Hypertext die wissenschaftliche Ergebnisdarstellung prägen und Online-Konferenzen zum Teil die Dienstreisen der Forschenden ersetzen. Doch welche Folgen wird der Interneteinsatz für die Wissenschaften haben? Kommt es zu Rollenverschiebungen zwischen den beteiligten Akteuren? Welche Folgen für räumliche Organisation von Forschung sind zu erwarten? Welche Implikationen hat diese Entwicklung für die Qualitätssicherung? Sind die aktuellen Regelungen des Urheberrechtsschutzes adäquat für die Cyberscience?
\end{abstract}

Das kürzlich abgeschlossene mehrjährige TAProjekt „Cyber-Wissenschaft", das am ITA in Wien durchgeführt wurde, gibt Antworten auf die oben aufgeworfenen Fragen (siehe schon Nentwich 1999b in dieser Zeitschrift). Dieser Beitrag kann aus Platzmangel nur einige Ergebnisse im Überblick darstellen. Genauere Ausführungen $\mathrm{zu}$ den aufgeworfenen Themen finden sich in Nentwich (2003). Die genannte Studie hat die IKT-Auswirkungen auf die Wissenschaften umfassend zum Thema gemacht. Hier beschränke ich mich auf folgende Aspekte: die Auswirkungen auf die Rollenverteilung im wissenschaftlichen Betrieb (1); die Wirkungen des verbesserten Zugangs zu Internetressourcen auf das wissenschaftliche Hierarchiesystem (2); die Notwendigkeit der Archivierung der zunehmend digitalen Bestände (3); die Bedeutung des Urheberrechts in diesem Zusammenhang (4) und schließlich die Qualitätssicherung in jenem Teil des Internets, welches die Wissenschaften zu ihrer internen Kommunikation benutzen (5).

\section{Rollenverschiebungen}

Der zunehmende Einsatz von IKT wirkt sich auf die Rollenverteilung in der Wissenschaft sowie auf die Anforderungen aus, die an einzelne Per 